\title{
PENGARUH PENDIDIKAN KESEHATAN IMUNISASI TERHADAP KECEMASAN ANAK PRA IMUNISASI DI KOTA TANGERANG TAHUN 2018
}

\author{
Endang Suartini, Dwi Aprilina Andriani \\ Poltekkes Kemenkes Banten \\ Korespondensi : endangkalbar@gmail.com
}

\begin{abstract}
The background of this research is fear and anxiety in children against immunization will cause reactions at the time of immunization. Some ways that can be done to reduce anxiety in children by providing information or health education related to immunization to children. The study aimed to determine the effect of immunization health education on the anxiety of preimmunization children. The study design used a quasi-experiment with the Pretest-Posttest Control Group Design approach. In this study, there are two groups, namely the intervention group and the control group in August and September. The sample of this study was elementary school students in Taman Sukarya 1 and 2 data were collected using a questionnaire sheet, the data were processed and analyzed by Univariate and B $i$ variant by Mann-Whitney test. research results show no effect of immunization health education on pre-immunization child anxiety $(p=$ 0.116 ).
\end{abstract}

Keywords: health education, anxiety, immunization

\begin{abstract}
ABSTRAK
Latar belakang penelitian ini adalah Ketakutan dan kecemasan pada anak terhadap imunisasi akan menimbulkan reaksi-reaksi pada saat dilakukan imunisasi. Beberapa cara yang bisa dilakukan untuk mengurangi kecemasan pada anak dengan memberikan informasi atau pendidikan kesehatan terkait imunisasi kepada anak. Tujuan penelitian adalah Untuk mengetahui pengaruh pendidikan kesehatan imunisasi terhadap kecemasan anak pra imunisasi Desain penelitian menggunakan quasi experiment dengan pendekatan Pretest-Posttest Control Group Design. Pada penelitian ini terdapat dua kelompok, yaitu kelompok intervensi dan kelompok kontroL pada bulan Agustus dan September. Sampel penelitian ini adalah siswa SD di Taman Sukarya 1 dan 2 data dikumpulkan menggunakan lembar kuesioner, data diolah dan dianalisis dengan Univariat dan Bivariat dengan uji mann-whitney. Hasil penelitian menunjukan tidak ada pengaruh pendidikan kesehatan imunisasi terhadap kecemasan anak pra imunisasi $(\mathrm{p}=0,116)$.
\end{abstract}

Kata kunci : pendidikan kesehatan, kecemasan, imunisasi 


\section{PENDAHULUAN}

Imunisasi adalah salah satu cara pencegahan penyakit menular. Imunisasi bermanfaat untuk menimbulkan atau meningkatkan kekebalan seseorang secara aktif terhadap suatu penyakit. Imunisasi terbuktti dapat mencegah dan mengurangi kejadian sakit, cacat dan kematian akibat Penyakit yang Dapat Dicegah Dengan Imunisasi (PD3I). Menurut World Health Association (WHO), Imunisasi campak di Indonesia sudah memiliki cakupan sebanyak $84 \%$ yang merupakan cakupan imunisasi campak sedang (Kemenkes, 2016).

Program imunisasi pemerintah diberikan kepada setiap bayi dan anak. Setelah mendapatkan imunisasi dasar lengkap pada saat bayi, anak membutuhkan imunisasi lanjutan, salah satunya adalah imunisasi campak. Pemberian imunisasi diberikan dalam kegiatan bulan imunisasi anak sekolah (BIAS) (Kemenkes, 2016). Anak sekolah yang mendapatkan imunisasi campak yang diberikan melalui injeksi subcutan akan menimbulkan ketakutan pada saat imunisasi. Ketakutan anak terhadap imunisasi akan menimbulkan kecemasan pada anak tersebut.

Ketakutan dan kecemasan pada anak terhadap imunisasi akan menimbulkan reaksi-reaksi pada saat dilakukan imunisasi. Reaksi tersebut antara lain menangis, berteriak, memukul, menahan diri dari prosedur, melarikan diri, menendang, sesak napas, dan pingsan (Rosiana dalam Irwinda dkk, 2017). Beberapa cara yang bisa dilakukan untuk mengurangi kecemasan pada anak dengan memberikan informasi atau pendidikan kesehatan terkait imunisasi kepada anak.

\section{METODE}

Penelitian ini dilakukan di Sekolah dasar pada bulan Mei sd Juli 2018. Populasi penelitian ini adalah siswa sekolah dasar Negri Sukasari 1, Kelas 1 untuk kelompok Intervensi, dan Sekolah dasar Negri 2, Kelas 1 untuk kelompok kontrol. Lokasi di kota Tangerang.

Sampel pada penelitian ini menggunakan perhitungan sampel dua kelompok dengan rumus :

$$
\begin{aligned}
& n_{1}=n_{2}=\left[\frac{Z \alpha \sqrt{2 P Q}+Z \beta \sqrt{P_{1} Q_{1}+P_{2} Q_{2}}}{P_{1}-P_{2}}\right]^{2} \\
& \text { Dimama: } \\
& P=\frac{P_{1}+P_{2}}{2} \\
& Q=1-P \text {. } \\
& Q_{1}=1-P_{1} \cdot Q_{2}=1-P_{2}
\end{aligned}
$$

Dengan kriteria inklusi:

1. Orangtua bersedia anaknya mendapatkan imunisasi 
2. Bersedia menjadi responden dan menandatangani inform consent.

Sedangkan kriteria eksklusi, yaitu:

1. Orang tua tidak bersedia anaknya di imunisasi

2. Tidak bersedia menjadi responden

Desain penelitian menggunakan quasi experiment dengan pendekatan PretestPosttest Control Group Design. Pada penelitian ini terdapat dua kelompok, yaitu kelompok intervensi dan kelompok kontrol. Instrumen pengumpul data pada penelitian ini menggunakan lembar pengumpul data karakteristik responden, dan kuesioner penilaian kecemasan anak.

Analisa data yang diperoleh data kecemasan anak sebelum dan sesudah pemberian pendidikan kesehatan imunisasi. Oleh karena itu, digunakan uji beda dua sampel berpasangan untuk skala ordinal yaitu mean - whitney dengan menggunakan program SPSS dengan tingkat kepercayaan $95 \%(\mathrm{p} \leq 0,05)$.

\section{HASIL DAN PEMBAHASAN}

1. Analisis Univariat

Pada analisis univariat ini menggambarkan distribusi frekuensi untuk mengetahui kecemasan yang dialami anak pra imunisasi sebelum diberikan intervensi. a. Karakteristik Responden berdasarkan usia

Tabel 1

Karakteristik Responden Berdasarkan usia

$$
(n=46)
$$

\begin{tabular}{lcccc}
\hline Usia Anak & Intervensi & Kontrol & \\
\cline { 2 - 4 } & Frek & $\%$ & Frek & $\%$ \\
\hline 7 Tahun & 2 & 8,7 & & \\
8 Tahun & 17 & 73,9 & 18 & 78,3 \\
9 Tahun & 4 & 17,4 & 5 & 21,7 \\
\hline
\end{tabular}

Tabel 1 Menunjukan bahwa sebagian besar pada Kelompok Intervensi berusia 8 tahun $(73,9 \%)$, dan pada kelompok Kontrol sebagaian besar berusia 8 tahun $(78,3 \%)$.

b. Karakteristik Berdasarkan Jenis Kelamin

Tabel 2 Karakteristik Berdasarkan Jenis Kelamin

\begin{tabular}{ccccc}
\hline \multirow{2}{*}{$\begin{array}{c}\text { Jenis } \\
\text { Kelamin }\end{array}$} & \multicolumn{5}{c}{ Kontrol } \\
\cline { 2 - 5 } & Frek & $\%$ & Frek & $\%$ \\
\hline Laki & 15 & 65,2 & 13 & 56,5 \\
Perempuan & 8 & 34,8 & 10 & 43,5 \\
\hline Tabel & 2 & & menunjukkan & bahwa
\end{tabular}
sebagian besar pada Kelompok intervensi adalah laki - laki sebanyak $15(65,2 \%)$ dan pada kelompok kontrol sebagian besar adalah kali - laki juga sebanyak 13 (56,5\%)

c. Tingkat Kecemasan

Tabel 3 Tingkat Kecemasan Pre Tes ( $n=46)$

\begin{tabular}{ccccc}
\hline Pre Test & \multicolumn{2}{l}{ Intervensi } & Kontrol \\
\cline { 2 - 4 } Kecemasan & Frek & $\%$ & Frek & $\%$ \\
\hline $\begin{array}{c}\text { Tidak } \\
\text { Cemas }\end{array}$ & 23 & 100 & 23 & 100 \\
Cemas & 0 & 0 & 0 & 0 \\
\hline
\end{tabular}


Tabel 3 menunjukkan bahwa sebagian bessar pada Pre test intervensi yang mengalami tidak cemas sebanyak 23 Responden (100\%) dan pada Pre btest Kontrol yang menunjukan tidak cemas $(100 \%)$

Tabel 4

Tingkat Kecemasan Post Test

\begin{tabular}{ccccc}
\hline Pre Test & \multicolumn{3}{c}{ Intervensi } & Kontrol \\
\cline { 2 - 4 } Kecemasan & Frek & $\%$ & Frek & $\%$ \\
\hline Tidak & 23 & 100 & 23 & 100 \\
Cemas & & & & \\
Cemas & 0 & 0 & 0 & 0 \\
\hline
\end{tabular}

Tabel 4 menunjukkan bahwa sebagian besar pada Post test intervensi yang mengalami tidak cemas sebanyah 23 Responden (100\%) dan pada Post btest Kontrol yang menunjukan tidak cemas sebanyak 23 responden (100\%).

d. Perbandingan tingkat kecemasan pada kelompok intervensi sebelum dan sesudah diberikan pendidikan kesehatan imunisasi

Tabel 5

Perbandingan Tingkat Kecemasan $(n=23)$

\begin{tabular}{lcc}
\hline & \multicolumn{2}{c}{ Kelompok Intervensi } \\
\cline { 2 - 3 } & Sebelum & Sesudah \\
\hline Mean & 5,48 & 2,00 \\
Standar & 6,089 & 3,503 \\
Deviasi & & \\
Minimal & 0 & 0 \\
Maksimal & 21 & 10 \\
\hline
\end{tabular}

Tabel 5 menunjukkan bahwa nilai rerata angka tingkat kecemasan pada kelompok intervensi sebelum dilakukan pendidikan kesehatan imunisasi adalah 5,48, sedangkan setelah dilakukan pendidikan kesehatan nilai rerata menjadi 2,00, sehingga terjadi penurunan pada nilai rerata sebelum dan sesudah dilakukan intervensi. Nilai maksimal yang diperoleh pada kelompok ini sebelum dilakukan pendidikan kesehatan adalah 21, dan nilai maksimal setelah dilakukan pendidikan kesehatan adalah 10. Nilai minimal sebelum dilakukan pendidikan kesehatan pada kelompok ini adalah 0 dan setelah dilakukan pendidikan kesehatan adalah 0 .

e. Perbandingan tingkat kecemasan pada kelompok kontrol sebelum dan sesudah diberikan pendidikan kesehatan imunisasi

Tabel 6

Perbandingan Tingkat Kecemasan $(n=23)$

\begin{tabular}{lcc}
\hline & \multicolumn{2}{c}{ Kelompok Kontrol } \\
\cline { 2 - 3 } & Sebelum & Sesudah \\
\hline Mean & 5,17 & 4,13 \\
Standar & 4,979 & 5,430 \\
Deviasi & & \\
Minimal & 0 & 0 \\
Maksimal & 19 & 19 \\
\hline
\end{tabular}

Tabel 6 menunjukkan nilai sebelum rerata angka tingkat kecemasan pada kelompok kontrol adalah 5,17, sedangkan 
saat setelah nilai rerata 4,13 , hal ini menunjukkan pada nilai rerata terjadi penurunan pada nilai rerata sebelum dan sesudah pada kelompok kontrol. Nilai maksimal pada saat sebelum dan sesudah adalah 19 .

\section{Analisis Bivariat}

Analisis yang digunakan dalam penelitian ini menggunakan analisis non parametric yaitu Wilcoxon Match Pair Test dan Mann Whitney U Test.

a. Perbandingan rerata tingkat kecemasan pada kelompok intervensi dan kelompok kontrol sebelum dan sesudah dilakukan pendidikan kesehatan imunisasi pada kelompok intervensi

\section{Tabel 7}

Perbandingan rerata tingkat kecemasan pada kelompok intervensi dan kelompok kontrol sebelum dan sesudah dilakukan pendidikan kesehatan pada kelompok intervensi

\begin{tabular}{|c|c|c|c|c|c|}
\hline Kelompok & Mean & SD & $\mathrm{Z}$ & $\mathrm{df}$ & $\begin{array}{c}P \\
\text { Value }\end{array}$ \\
\hline \multicolumn{6}{|l|}{ Intervensi } \\
\hline $\begin{array}{l}\text { Sebelum } \\
\text { Sesudah } \\
\text { Perbedaan }\end{array}$ & $\begin{array}{l}5,48 \\
2,00 \\
3,48\end{array}$ & $\begin{array}{l}6,089 \\
3,503\end{array}$ & $2, \overline{7} 50$ & 23 & 0,006 \\
\hline \multicolumn{6}{|l|}{ Kontrol } \\
\hline $\begin{array}{l}\text { Sebelum } \\
\text { Sesudah } \\
\text { Perbedaan }\end{array}$ & $\begin{array}{l}5,17 \\
4,13 \\
1,04\end{array}$ & $\begin{array}{l}4,979 \\
5.430\end{array}$ & $\begin{array}{c}- \\
1,899\end{array}$ & 23 & 0,058 \\
\hline
\end{tabular}

Ket: *bermakna/signifikan pada $a=0,05$

Tabel 7 menunjukkan rata-rata tingkat kecemasan pada Anak Pra Imunisasi sebelum dilakukan pendidikan kesehatan imunisasi pada kelompok intervensi adalah 5,48 dengan standar deviasi 6,089 dan setelah dilakukan pendidikan kesehatan imunisasi adalah 2,00 dengan standar deviasi 3,503. Analisa lebih lanjut adanya perbedaan bermakna antara tingkat kecemasan pada kelompok intervensi sebelum dan sesudah dilakukan pendidikan kesehatan imunisasi dengan kata lain ada perbedaan signifikan bahwa pendidikan kesehatan imunisasi dapat menurunkan rata-rata tingkat kecemasan pada Anak Pra Imunisasi kelompok intervensi sebesar 3,48 $(\mathrm{p}$ value $=0,006$ $a=0,05)$.

b. Perbandingan rerata tingkat kecemasan antara kelompok intervensi dan kelompok kontrol setelah diberikan Intervensi pada kelompok Intervensi Tabel 8

Perbandingan rerata tingkat kecemasan pada Anak Pra Imunisasi antara Kelompok Intervensi dan Kelompok Kontrol setelah dilakukan intervensi

\begin{tabular}{ccccc}
\hline Kelompok & $\mathrm{n}$ & Mean & $\mathrm{df}$ & Sig \\
\hline Intervensi & 23 & 20,65 & \multirow{2}{*}{46} & 0,116 \\
Kontrol & 23 & 26,35 & &
\end{tabular}

Ket: *bermakna/signifikan pada $a=0,05$

Tabel 8 diatas menunjukkan hasil analisis perbedaan rata-rata tingkat kecemasan setelah diberikan pendidikan kesehatan imunisasi pada kelompok intervensi dan kelompok kontrol 
menggunakan Uji Mann Whitney U Test didapatkan mean intervensi $=20,65$, mean kontrol $=26,35$ dan $p$ value $=0,116(a=$ 0,05), maka dapat disimpulkan bahwa tidak terdapat perbedaan yang signifikan pada rata-rata tingkat kecemasan setelah diberikan pendidikan kesehatan imunisasi pada kelompok intervensi dan kelompok control

Pada Penelitian ini dengan judul Pengaruh Pendidikan Kesehatan Imunisasi Terhadap Kecemasan Anak Pra Imunisasi dengan menggunakan uji Mann - Whitney didapatkan hasil $0,116(>0,05)$ yang berarti tidak ada pengaruh pendidikan kesehatan imunisasi terhadap kecemasan anak pra imunisasi, hal ini tidak sejalan dengan penelitian Hubungan kecemasan ibu tentang efek samping imunisasi DT dengan pemberian Imunisasi DT, dimana $\mathrm{p}<0,000$ karena hal ini perlu adanya dukungan dari para kader dan teman ibu yang sudah pernah memberikan imunisasi kepada anak agar ibu yang lain mau memberikan imunisasi kepada anak dan tidak takut terhadap efek samping imunisasi.

Mungkin hal ini juga berhubungan dengan adanya kampanye imunisasi tambahan DT diwilayah Jakarta - Banten pada bulan agustus - September 2018 yang diselenggaraakan di Sekolah, Namun ada saja yang menolak imunisasi tersebut, dikarenakan keraguan akan bahan imunisasinya tersebut.

Fatwa Majelis Ulama Indonesia (MUI) NO 4 Tahun 2016 dijelaskan bahwa imunisasi pada dasarnya di bolehkan (mubah) sebagai bentuk ikhtiar untuk mewujudkan kekebalan tubuh dan mencegah terjadinya suatu penyakit tertentu. Tentang vaksin inipun sudah jelas dan sejalan denga (Hr. Muslim Ahmad dan an Nasai yang berbunyi " diriwayatkan dari Jabir, dari Rasulullah SAW, bahwa beliau bersabda: Setiap penyakit ada obatnya, maka penyakit telah dikenakan obat, semoga sembuh dengan ijin Allah dalam penelitian Lailah Najah dan Evi Nurhidayati. Dan dapat dimungkinkan juga, tidak ada pengaruh pendidikan kesehatan imunisasi terhadap kecemasan anak pra imunisasi dikarenakan anak sudah mendapatkan suntikan DT sebanyak dua kali, yaitu pada bulan November 2017, bulan Desember 2017 dan yang ketiga di bulan Agustus 2018, hal ini karena sudah berulang sehingga terbiasa bagi anak.

\section{SIMPULAN}

Berdasarkan hasil penelitian di SDN Taman Sukarya dapat disimpulkan : tidak ada pengaruh $(\mathrm{p}=0,116)$ pendidikan kesehatan imunisasi terhadap kecemasan anak pra imunisasi dan ada beda tingkat kecemasan sebelum dan sesudah dilakukan 
tindakan perlakuan. Peneliti menyadari bahwa hasil penilitian ini belum sempurna, oleh karena itu penulis memberikan saran adanya penelitian lebih lanjut terkait jumlah responden yang lebih besar dan variabel - variabel tentang komunikasi pra imunisasi.

\section{UCAPAN TERIMA KASIH}

Penulis mengucapkan terima kasih kepada Poltekkes Kemenkes Banten yang telah membiayaai penelitian ini.

\section{DAFTAR RUJUKAN}

Fitriani, S. 2011. Promosi Kesehatan. Yogyakarta : Graha Ilmu

Hockenberry, MJ \& Wilson, D. 2009. Essential Of Pediatric Nursing. St. Louis Missoury: Mosby

Irwinda F., Mariyam, Mubiin, MF. 2017. Gambaran kecemasan anak usia toodler saat imunisasi yang diberi distraksi video film kartun di Puskesmas Bugangan Semarang. Skripsi yang dipublikasikan. Keperawatan Fikkes UNIMUS

Kemenkes RI. 2016. Situasi Imunisasi di Indonesia. InfoDATIN. http://www.depkes.go.id, diakses tanggal 11 September 2017
Lailah Najah dan Evi Nurhidayati. 2017. Penelitian Tingkat pengetahuan ibu tentang imunisasi tambahan MR (Measles Rubella) pada balita di Puskesmas Kota Gede I Yigyakarta 2017

Mahfoed I dan Suryani E. 2006. Pendidikan Kesehatan Bagian Dari Promosi Kesehatan. Yogyakarta : F Tranaya

Maryuani, A. 2010. Ilmu Kesehatan Anak dalam kebidanan. Jakarta : CV. Trans Info Media

Maria Haryanti Butarbutar. 2018. Jurnal Penelitian. Hubungan kecemasan ibu tentang efek samping imunisasi DPT dengan pemberian Imunisasi DPT

Potter \& Perry. 2005. Fundamental Keperawatanj konsep, proses dan praktis edisi 4. Vol 1. Jakarta : EGC

Ramadini Marniaty de Breving, dkk. 2015. Pengaruh Penerapan autramatic care terhadap respon kecemasan Anak Yang Mengalami Hospitalisasi di RSU Pancaran Kasi GMIM Manado dan RSUP DR. R D Kanadau Manado. E Jurnal Keperawatan Volume 3 Nomor 2 Mei 2015 
Setiadi, 2012. Konsep dan praktik Penulisan Riset Keperawatan. Yogyakarta: Graha Ilmu

Wong, D.L,dkk.2009. Buku Ajar Keperawatan Pediatrik Vol 1. Jakarta : EGC 